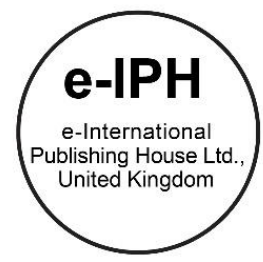

\title{
Right to Privacy and Malaysian Practice: A step further in recognising another aspect of human rights
}

\author{
Normawati Hashim ${ }^{1}$, Abd Shukor Mohd Yunus ${ }^{2}$ \\ ${ }^{1}$ Associate Professor, Faculty of Law, Universiti Teknologi MARA, 40450 Shah Alam, Selangor, Malaysia \\ ${ }^{2}$ Doctor of Law Candidate, Faculty of Law, Universiti Teknologi MARA, 40450 Shah Alam, Selangor, Malaysia \\ busuwati@yahoo.com¹, shux.yunus@gmail.com² \\ Tel:+60 133930535
}

\begin{abstract}
Privacy is an individual right that is fundamental to protect the dignity of a person, especially in the technological era. Currently, privacy is not part of human right under the Malaysian Federal Constitution. Conversely, European Union, South Africa, Hong Kong, and India were advance in the recognition. This is qualitative research analysing the need to move forward in recognising privacy as part of human right with reference to the practice of the European Union, South Africa, Hong Kong, and India. The outcome of the study is proposing a legal framework recognising privacy as a basic human right in Malaysia
\end{abstract}

Keywords: privacy; human rights; fundamental liberties; external intrusion

eISSN: 2398-4287@ 2020. The Authors. Published for AMER ABRA cE-Bsby e-International Publishing House, Ltd., UK. This is an open access article under the CC BYNC-ND license (http://creativecommons.org/licenses/by-nc-nd/4.0). Peer-review under responsibility of AMER (Association of Malaysian Environment-Behaviour Researchers), ABRA (Association of Behavioural Researchers on Asians) and cE-Bs (Centre for Environment-Behaviour Studies), Faculty of Architecture, Planning \& Surveying, Universiti Teknologi MARA, Malaysia.

DOI: https://doi.org/10.21834/ebpj.v5iSI3.2570

\subsection{Introduction}

Privacy forms part of fundamental rights enshrined in the United Nations Declaration of Human Rights and the International Covenant on Civil and Political. ${ }^{*}$ According to the Privacy International report ${ }^{\dagger}$, privacy underpins human dignity and other key values such as freedom of association and freedom of speech. The report explained that privacy is an important human rights issue of the modern age. Although there is no universally accepted definition of the right to privacy, privacy protection is frequently seen as a boundary of how far society may intrude into a person's private affairs. $\ddagger$ Very progressive advancement of the technologies definitely serves a good purpose; however, there were reports that the technologies (i.e. social media, online service providers who collect personal data such

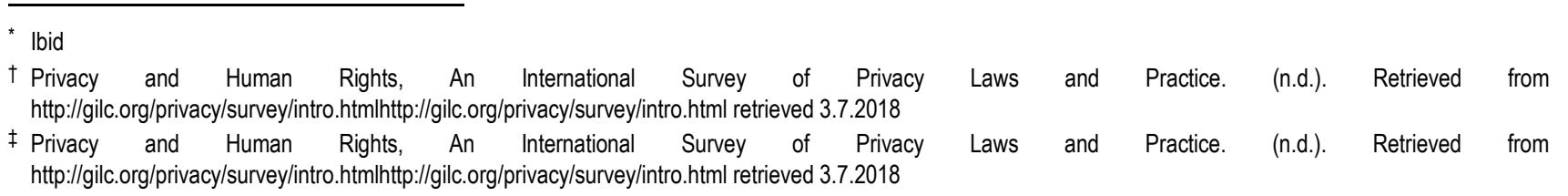

eISSN: 2398-4287@ 2020. The Authors. Published for AMER ABRA cE-Bsby e-International Publishing House, Ltd., UK. This is an open access article under the CC BYNC-ND license (http://creativecommons.org/licenses/by-nc-nd/4.0/). Peer-review under responsibility of AMER (Association of Malaysian Environment-Behaviour Researchers), ABRA (Association of Behavioural Researchers on Asians) and cE-Bs (Centre for Environment-Behaviour Studies), Faculty of Architecture, Planning \& Surveying, Universiti Teknologi MARA, Malaysia. DOI: https://doi.org/10.21834/ebpj.v5iSI3.2570 
as Google, surveillance and monitoring, Global Positioning System (GPS) etc.) were causing new concerns about the privacy breach.\$ It was reported that many of these technologies are operating outside the jurisdiction of legal and enforcement authorities. ${ }^{* *}$ Henceforth, this study aims to establish the legal framework to encode the right to privacy as part of the fundamental right. Based on a qualitative research method, this paper will examine the availability of international, regional, and domestic legal instruments, and public law jurisprudence on the recognition on the right to privacy as part of human rights.

The outcome of the study is the creation of such a proposed legal framework that recognises privacy as a basic human right. The proposed model is a significant first step for countries that have yet to recognise the right to privacy a human right.

\subsection{Privacy}

\subsection{Definition of privacy}

Privacy, in general, means a condition where a person is not being monitored or subject to be bothered by other people, as well as a situation where a person is free from public attention. ${ }^{\dagger \dagger}$ In addition, it may also be defines as a person's right to keep their personal matters and relationship a secret and a situation where they are being left alone. private and undisturbed, and freedom from intrusion or public attention. $\$ \$$ Meanwhile, the Calcutt Committee of United Kingdom defined privacy as the right of an individual to be protected against intrusion into his personal life or affairs, or those of his family, by direct physical means or by the publication of information."

\subsection{Importance on the protection of privacy}

The importance of privacy was first highlighted by Warren and Brandeis, ttt where they opined that privacy is an important element in any democracy and should be reflected in a state's Constitution. According to them, privacy may be generalized to constitute 'right to be let alone'. This right proposes the right to life to be interpreted broadly, to include the right to enjoy life without external interference and pressure. Failure to safeguard the right to be let alone will jeopardise the personal activity of the individual. The opinion was further supported by Alan F. Westin where he defined privacy as the desire of a person to choose freely under certain circumstances, the extent of self-expose, attitude and behaviour to others. $¥ \neq \ddagger$ For these reasons mentioned, it is important to guarantee the right to privacy.

With the growing advances of the technology, there is an emergence of cases on intrusion on a person's privacy. As privacy involved personal affairs that affect the personal life of a person, any intrusion of personal life would have a serious impact on his dignity. Thus, identifying the legal status of the right to privacy is vital.

Protection of one's privacy is vital in protecting the emotional state of the affected person, the ethical state of practice, as well as the economics repercussion (positive and negative) when the law is put in place. For instance, a person whose private life has been invaded by the third party will have emotional instability and insecurity, where it may impact their daily routine, socially and economically.

On the ethical point of view, without the slightest protection of privacy, with a vast technology nowadays, it is not impossible for a person to misuse such a facility to instigate harm onto others. For example, a person may casually upload a photo or video to a website that humiliates another individual. It is ethically wrong; however, since there are no legal provision and protection for privacy, hence, there is no repercussion towards the uploader. In addition, without proper protection of privacy in place, there will be no moral or ethical protection to guide the right and wrong.

As for economic repercussion, with privacy is being protected, it will increase the security of data handling, especially for the companies who are handling informal data such as Google and Facebook. With protection put in place, it may increase the trust of a person to the system or service providers, which hence, may give an economic boost to the business.

\subsection{Legal status on the right to privacy}

As far as international law is concerned, the right to privacy has received recognition as part of human rights under the Universal Declaration of Human Rights and International Covenant on Civil and Political Rights. According to Article 12 of the Universal Declaration of Human Rights, a person is deemed to be protected against any interference with his privacy, family, home or correspondence, honour and reputation. A similar provision is also found in Article 17 of the International Covenant on Civil and Political Rights. Based on the provision, privacy forms part of fundamental rights recognised under the international legal instruments.

t† https://en.oxforddictionaries.com/definition/privacy

\# $\quad$ https://dictionary.cambridge.org/dictionary/english/privacy

$\S \S \quad$ http://english.oxforddictionaries.com/definition/privacy

*** Carter-Ruck, P. F. (1990), The calcutt report of the committee on privacy and related matters. International Legal Practitioner 15(3), 72-73.

tt† Samuel D Warren, Louis D Brandeis (1890), The Right to Privacy, Harvard Law Review, Vol 4, No 5. (Dec 15, 1890)

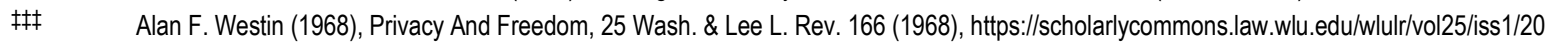


However, the international legal instrument is soft laws, and the effective implementation of the provisions could only be made through the enactment of the domestic law.

European Union and other countries such as South Africa, Hong Kong and India have moved forward in implementing the fundamental right to privacy into their domestic laws. The recognition comes in the form of constitutional, convention, statutory provisions, or case law. Article 8 of the European Convention of Human Rights has clearly provided for a specific provision in addressing privacy as part of rights which shall be enjoyed by a person. Meanwhile, Article 14 of the Constitution of the Republic of South Africa clearly emphasized on privacy as a matter of fundamental right.

Further, in Hong Kong, Article 14 of the Bill of Rights Ordinance (Cap 383) recognise privacy as part of fundamental liberties. On the other hand, India through the case of Justice KS Puttaswamy (Retired) \& Anor v Union of India \& Ors (Aadhaar case)\$\$\& chaired by a nine-judge bench and headed by Chief Justice $\mathrm{J} S$ Khehar, decided unanimously, that right to privacy forms as an intrinsic part of fundamental liberties.

India and Malaysia started out as countries that were colonized by British, yet post-Independence, India seems to be more progressive and step further ahead as compared to Malaysia, in terms of safeguarding basic human rights. The dynamic attitude of other jurisdictions could serve as a model of reference to countries who have yet to develop an explicit legal framework on the right to privacy. Malaysia is one of the countries that need certainty on the legal status on the right to privacy.

\subsection{Right to privacy in Malaysia}

\subsubsection{Judicial uncertainty on the right to privacy}

There is uncertainty on the legal status of the right to privacy under Malaysian law. Although the Malaysian Federal Constitution has provisions on fundamental rights, there is no provision on the right to privacy."*t* The Malaysian Data Protection Act 2010, on the other hand, was enacted to protect the personal information of an individual, the law governs mainly on commercial transactions. Other aspects of human dignity were not covered under the Act. The absence of an express provision on the right to privacy has led to an uncertainty on the governance of privacy right in Malaysia. Due to this uncertainty, it just seems right for us to either incorporate protection of privacy in the Federal Constitution or to have a specific law governing such protection. In the case of Sivarasa Rasiah $v$ Badan Peguam Malaysiatttt the court mentioned that Article 5(1) of the Federal Constitution guarantees protection of life and personal liberty of a person, but the court never elaborated its opinion further whether it wishes to confirm the claims on privacy invasion.

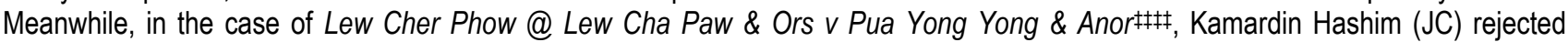
Plaintiff's claims for a permanent interlocutory injunction, in removing the CCTV camera installed by the Defendant which was pointed at the Plaintiff's house. With regards to privacy right, the court in its decision makes references to the case of Ultra Dimension Sdn Bhd v Kook Wei Kuan\$\$\$, where the court decided that since the English common law does not recognise privacy rights, invasion of privacy does not give rise to a cause of action in Malaysia. Hence, it was decided that the respondent had no right to institute an action against the appellant for an invasion of privacy rights.

Conversely, in the retrial of Lew Cher Phow @ Lew Cha Paw \& Ors v Pua Yong Yong \& Anor ${ }^{*+* * * *}$ before Vernon Ong J, the Plaintiff brought the case of private nuisance where Defendant's CCTV camera no 3 was directed and focused at and monitoring and capturing images of the Plaintiff's courtyard. The court, in this case, recognised the Plaintiff's right to privacy, where the Defendant's action has caused the Plaintiff to suffer emotional stress, strain, and medical complication. In this case, the court highlighted two competing values in its judgement, i.e., safety and privacy, and whether Defendants' fear for their safety and security may override Plaintiffs' right to privacy. The court decided that the overt surveillance carries an implied threat which may undermine the Plaintiffs' dignity, self-esteem, comfort, and privacy.

The abovementioned two cases (first in 2009 and the retrial was in 2011) was brought to the Johor Bahru High Court for the same intention, where the CCTV installed by the Defendant cause a nuisance to the Plaintiff, but on different grounds altogether. The absent of cause of action for the protection of privacy causes the delay for the Plaintiff to address the case appropriately before the court. However, Vernon Ong $\mathrm{J}$ recognized right to privacy as part of a fundamental right, and hence the privacy of the Plaintiff should be protected.

In the case of Dr Bernadine Malini Martin v MPH Magazine Sdn Bhd \& Ors and another Appea/ttttt, the court opined that it is unethical and morally wrong for any party to publish one's photograph in a magazine for public circulation without consent. Even though it is for the intention of commercial promotion, but without one's consent, the deed is wrongly done. This may be presumed as an unwarranted invasion of the person's privacy.

\footnotetext{
§§§ Justice KS Puttaswamy (Retired) \& Anor v Union of India \& Ors (Aadhaar case) WP (Civil) No 494/2012, 24 August 2017

Duryana Mohamed (2016), The Privacy Right and Right to be Forgotten: the Malaysian Perspectives. Indian Journal of Science and Technology, [S.I.], dec 2016. ISSN 0974 -5645. doi:10.17485/ijst/2016/v9iS1/106854

ttt† Sivarasa Rasiah v Badan Peguam Malaysia [2010] 2 MLJ 333

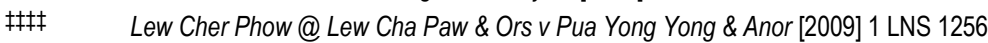

§§§§ Ultra Dimension Sdn Bhd v Kook Wei Kuan [2004] 5 CLJ 285, [2001] MLJU 751

**** Lew Cher Phow @ Lew Cha Paw \& Ors v Pua Yong Yong \& Anor [2011] 1 LNS 1528, [2011] MLJU 1195

tttt† Dr Bernadine Malini Martin v MPH Magazine Sdn Bhd \& Ors and another Appeal [2010] 7 CLJ 525
} 
Dr Bernadine's case also highlighted the case of Ultra Dimension Sdn Bhd v Kook Wei Kuanłłłłł showing the set back of the Malaysian legal framework. In the latter, the court held that the invasion of privacy does not fall within any boundary of a recognised and existing tort, resulting in not giving rise to the cause of action. Nonetheless, in the obiter of this case, the court commented that a cause of action might arise if the photograph were highly offensive in nature and showed a person in an embarrassing position or pose.

Although the case such as Dr Bernadine and Ultra Dimension support the protection of one's privacy, yet the jurisprudence on such protection is uncertain. With the growth and advancement of the internet and social media, network feasibility becomes more intrusive. Individual privacy is at stake whenever information is shared online, which is prone to others' surveillance and observation. The 'balcony sex case' is an example. $\$ \$ \$ \$$ In this case, a couple's sexual act at the balcony was recorded by a third party. The video was later uploaded to the online streaming media. Although the indecent act must not be condoned, the availability of such a video on the internet shows how thin the protection of one's privacy in the country.

Cases on privacy may have been attempted to be brought to the court as early as the new millennium. In the case of Poly Electronics \& Electrical (M) Sdn Bhd v Daewoo Corporation (No 1) 'The Mareva Injunction and Related Orders' (1985). The court pointed out:

... a party may apply to inspect the banking accounts and records of another party under section 7 of the Banker's Book Evidence Act 1879, which allows the court to make an order permitting any party to a legal proceeding to inspect and take copies of entries in a banker's books, so long the inspection is in furtherance of the proceedings ... As Lord Widgery explained in Williams and Ors v Summerfield [1972] 2 QB 513 (DC):

One must ... recognise that an order under section 7 can be a very serious interference with the liberty of the subject. It can be a gross invasion of privacy; it is an order which clearly must only be made after the most careful thought and on clearest grounds.

In the abovementioned case, the court recognised the implication of a certain level of permission given, which may lead to an act of invasion of privacy. Therefore, even after consent is obtained, the party who has been given such permission must handle information diligently to avoid the possibility of an invasion of privacy. However, it is noted that the case mentioned is a case dealing with information on a commercial transaction which is within the purview of private law.

Other cases on privacy include the decision of the court in Yushri Zainudin v Silterra Malaysia Sdn Bhd (Wafer Technology (Malaysia) Sdn Bhdtttttt. In the current case the court strikes out Plaintiff's claim due to insufficiency of particulars to establish the element of breach of privacy, and the heavy reliance on section 7(1) the Whistleblower Protection Act 2010 while neglecting section 15(1) of the Act.

In Toh See Wei v Teddric Jon Mohr \& Anorłtłtłł, the Court held that the alleged privacy of the emails itself is not a sufficient ground in the circumstances of the case. The court also referred to the case of Beatrice a/p AT Fernandez $v$ Sistem Penerbangan Malaysia \& Ors§§§§§§, where it was decided that the right to privacy under the Federal Constitution is not enforceable between private individuals.

While in Normal Ahmad @ Saliman v Sistem Televisyen Malaysia Berhad (known as TV3) \& Ors ${ }^{* * * * * *}$, the court awarded Plaintiff with RM100,000 damages for libel, while other claims (trespass/invasion of privacy/aggravated damages/exemplary damages) are not allowed since the Defendant has committed no civil wrong.

The cases above indicate that the jurisprudence legal framework on the right to privacy in Malaysia is uncertain. The unclear legal status on the right to privacy has led to confusion as to the right jurisprudence to be adopted by the Malaysian system. Apart from case law, the opinion of Dr Nehaluddin Ahmad on the issue of privacy is also relevant in understanding the reasons for the uncertainty on the legal status of the right to privacy in Malaysia. According to him, the term 'privacy' is a very difficult subject to be defined and

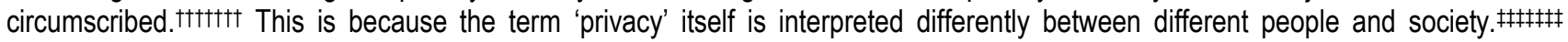
Meanwhile, there are several laws, which include the law of torts, contract, criminal, family and constitution, that may govern the issue of privacy of an individual. This add on to the uncertainty of the specific legal status of the right to privacy. $\S \S \S \S \S \S$

Hence, to overcome the uncertainty on the Malaysian jurisprudence on the right to privacy, reference should be made to the progressive development in the Indian jurisdiction. As the relevant provisions in the Indian Constitution, such as Article 21 and Article 14 are similar to Article 5(1) and Article 8(1) of the Malaysian Federal Constitution respectively, the Indian jurisprudential model can be referred to as a guideline. This is elaborated further below.

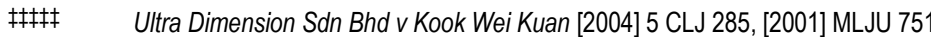

$\S \S \S \S \S$ Bedi, R. S. (2015). Balcony sex couple may be charged for gross indecency, says lawyer. Retrieved from https://www.thestar.com.my/news/nation/2015/05/14/balcony-sex-lawyer-gross-indecency/ Poly Electronic \& Electrical (M) Sdn Bhd v Daewoo Corporation (No 1) [2003] 6 CLJ 72

ttttt† Yushri Zainudin v Silterra Malaysia Sdn Bhd (Wafer Technology (Malaysia) Sdn Bhd [2017] 1 LNS 2187

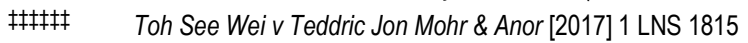

§§§§§§ Beatrice a/p AT Fernandez v Sistem Penerbangan Malaysia \& Ors [2005] 3 MLJ 681

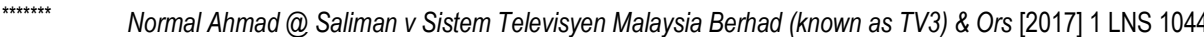

tttttt† Dr Nehaluddin Ahmad, 'The Right to Privacy and Challenges: A Critical Review' [2008] 5 MLJ cxxi, LexisNexis

$\ddagger \ddagger \ddagger \ddagger \ddagger \ddagger \ddagger$ Dr Nehaluddin Ahmad, 'The Right to Privacy and Challenges: A Critical Review' [2008] 5 MLJ cxxi, LexisNexis

§§§§§§§ Ibid 


\subsubsection{Legal Framework on Right to Privacy}

Despite the legislature attempts to emphasize the importance of one's personal data through the enactment of the Malaysian Personal Data Protection Act 2010, the Act does not cover the area on the invasion of a person's privacy under the public law. Although it is claimed that this Act was the first being introduced in South-East Asia region, it merely comprises of protection on formal data held by institutions, rather than other types of data including the information held by third parties over a person. The personal data covers the information that relates to data that is subject to who is identifiable from that information. This broad definition covers information such as names, contact details, national registration identity card numbers, and passport numbers. Personal data under the Act also includes any sensitive personal data such as the physical or mental health of that data subject, his political opinions and religious beliefs, and criminal convictions, among others. ${ }^{*}$ Other areas ranging from photographs, images from CCTV recording, the

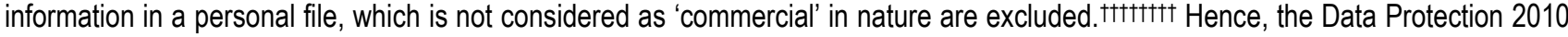
has a limited application as far as the right to privacy is concerned.

Apart from that, the Federal Constitution has no explicit provision on the right to privacy. What the Federal Constitution has is the provision on the right to life as stipulated under Article 5(1). According to the case of Tan Tek Seng v Suruhanjaya Perkhidmatan Pendidikan \& Anorłłtłłtłł, the term 'life' means life under Article 5(1) to include all facets that are pertinent to form the quality of life and all matters that are essential to human living. However, so far, the Malaysian court has not interpreted the meaning of life to include protection of the dignity of a person against any intrusion of personal privacy.

On the other hand, in India, using the similar provision on the right to life stipulated under Article 21 of the Indian Constitution, the Supreme Court in its recent decision in Puttaswamy (Retired) \& Anor v Union of India \& Ors (Aadhaar case)\$\$s\$\$\$§§ decided unanimously that right to privacy forms an intrinsic part of fundamental liberty as protected under Article 21 of its Constitution. According to Justice D.Y. Chandrachud:

Life and personal liberty are inalienable to human existence ... The human element in the life of the individual is integrally founded on the sanctity of life ... A constitutional democracy can survive when citizens have an undiluted assurance that the rule of law will protect their rights and liberties against any invasion by the state and that judicial remedies would be available to ask searching questions and expect answers when a citizen has been deprived of these most precious rights. ${ }^{* *+* t+x+* * t}$

The court in the above judgement has taken a dynamic approach in interpreting the right to life under Article 21. In its interpretation, the court construes the true meaning of life in the context of constitutional democracy read together with the protection afforded under the concept of the rule of law. The liberal interpretation allowed the court to creatively interpret life afforded under Article 21 to include right for the protection of an individual's privacy. It is also important to note that the recognition that right to privacy form part of fundamental right under Article 21 by the Indian jurisdiction is in line with the international standard as specified under Article 12 of the Universal Declaration of Human Rights and Article 17 of the International Covenant on Civil and Political.

Malaysia, whose provision under Article 5(1) of the Federal Constitution is similar to Article under 21 of the Indian Constitution should adopt a similar approach in interpreting the legal status of the right to privacy. The Court of Appeal in Tan Tek Seng $v$ Suruhanjaya Perkhidmatan Pendidikan \& Anorttttttttt defined the term 'life' under Article 5(1) to incorporate all facets that are an integral part of life itself, and those matters which form the quality of life. Meanwhile, Article 8(1) provides that everyone is equal before the law and received equal protection before the law. The intrusion of a person's privacy that affects the dignity of an individual is part of matters that is an integral part of the life of a person that form the quality of life, and this life must be given equal protection under the constitution. Hence, using the Indian jurisprudence and constitutional framework as a model, Malaysia is capable of recognising the right to privacy as part of a fundamental right protected under Article 5(1) read together with Article 8(1).

Besides, the Malaysian legislature should also learn from other jurisdictions on the enactment of the legal instrument in enacting law governing the right to privacy as part of fundamental human right. Countries such as the European Union, South Africa and Hong Kong, could be referred to as models for reference. Article 8 of the European Convention of Human Rights has clearly provided for a specific proviso in addressing privacy as part of rights which shall be enjoyed by a person. Meanwhile, Article 14 of the Constitution of the Republic of South Africa clearly emphasized on privacy as a matter of fundamental right. Hong Kong too under Article 14 of Bill of Rights Ordinance (Cap 383) recognised privacy as part of fundamental liberties. Learning from the European Convention of Human Rights, Constitutions of South Africa and Hong Kong, Malaysian could revisit its Constitutional provisions to make some necessary amendment to explicitly include protection of a person's privacy.

\footnotetext{
Donovan, C. (n.d.). Up Close and Personal: The Malaysian Personal Data Protection Act. Retrieved July 17, 2018, from https://www.hg.org/article.asp?id=33273

tttttttt Online, T. S. (2015, October 17). What you need to know about the PDPA. Retrieved from https://www.thestar.com.my/opinion/letters/2012/12/30/whatyou-need-to-know-about-the-pdpal

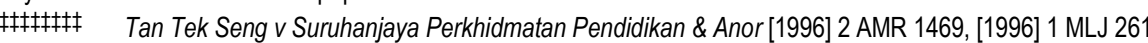

$\S \S \S \S \S \S \S$ Puttaswamy (Retired) \& Anor v Union of India \& Ors (Aadhaar case) WP (Civil) No 494/2012, 24 August 2017

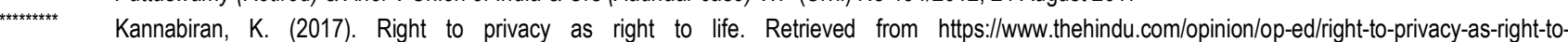
life/article20005285.ece

tttttttt Tan Tek Seng v Suruhanjaya Perkhidmatan Pendidikan \& Anor [1996] 2 AMR 1469, [1996] 1 MLJ 261
} 


\subsection{Conclusion}

To conclude, a strong legal framework is needed to protect the privacy of a person against any unlawful intrusion by a third party. The recognition by the United Nation Declaration of Human Rights and the International Covenant on Civil and Political Rights that right to privacy is part of human right, illustrate that fundamental right to privacy has been given international protection. Hence, countries like the European Union, South Africa, Hong Kong and India have given recognition on the right to privacy as part of human right protection. The innovative move by these jurisdictions could be used as a benchmark, and a source of reference by countries who have yet to develop such recognition and Malaysia is one of them. The unclear legal status of privacy rights in Malaysia has caused conflicting decisions in case law. To overcome the current weaknesses in the present Malaysian legal framework and jurisprudence, Malaysia could refer to European Union Convention of Human Right and the South Africa and Hong Kong constitutions as reference. Meanwhile, in terms of developing jurisprudence on the fundamental right to privacy, the Indian jurisprudence could be used as a model with some modification made to suit the local user. As the relevant provisions from the Indian Constitution, particularly Article 21 and 14 are similar to Article 5(1) and Article 8(1) of the Malaysian Federal Constitution, reference to the former would provide a guideline on the proper interpretation on the right to privacy in Malaysia.

\section{References}

Alan F. Westin (1968), Privacy And Freedom, 25 Wash. \& Lee L. Rev. 166 (1968), https://scholarlycommons.law.wlu.edu/wlulr/vol25/iss1/20

Beatrice a/p AT Fernandez v Sistem Penerbangan Malaysia \& Ors [2005] 3 MLJ 681

Bedi, R. S. (2015). Balcony sex couple may be charged for gross indecency, says lawyer. Retrieved from https://www.thestar.com.my/news/nation/2015/05/14/balconysex-lawyer-gross-indecency/

Carter-Ruck, P. F. (1990), The Calcutt report of the committee on privacy and related matters. International Legal Practitioner 15(3), 72-73.

Donovan, C. (n.d.). Up Close and Personal: The Malaysian Personal Data Protection Act. Retrieved July 17, 2018, from https://www.hg.org/article.asp?id=33273

Dr Bernadine Malini Martin v MPH Magazine Sdn Bhd \& Ors and another Appeal [2010] 7 CLJ 525

Dr Nehaluddin Ahmad, 'The Right to Privacy and Challenges: A Critical Review' [2008] 5 MLJ cxxi, LexisNexis

Duryana Mohamed (2016), The Privacy Right and Right to be Forgotten: the Malaysian Perspectives. Indian Journal of Science and Technology, [S.I.], dec. 2016. ISSN 0974 -5645. DOI:10.17485/ijst/2016/v9iS1/106854

http://english.oxforddictionaries.com/definition/privacy

https://dictionary.cambridge.org/dictionary/english/privacy

https://en.oxforddictionaries.com/definition/privacy

Justice KS Puttaswamy (Retired) \& Anor v Union of India \& Ors (Aadhaar case) WP (Civil) No 494/2012, 24 August 2017

Kannabiran, K. (2017). Right to privacy as right to life. Retrieved from https://www.thehindu.com/opinion/op-ed/right-to-privacy-as-right-to-life/article20005285.ece

Lew Cher Phow @ Lew Cha Paw \& Ors v Pua Yong Yong \& Anor [2009] 1 LNS 1256

Lew Cher Phow @ Lew Cha Paw \& Ors v Pua Yong Yong \& Anor [2011] 1 LNS 1528, [2011] MLJU 1195

Normal Ahmad @ Saliman v Sistem Televisyen Malaysia Berhad (known as TV3) \& Ors [2017] 1 LNS 1044

Online, T. S. (2015, October 17). What you need to know about the PDPA. Retrieved from https://www.thestar.com.my/opinion/letters/2012/12/30/what-you-need-toknow-about-the-pdpal

Poly Electronic \& Electrical (M) Sdn Bhd v Daewoo Corporation (No 1) [2003] 6 CLJ 72

Preamble, Personal Data Protection Act 2010

Privacy and Human Rights, An International Survey of Privacy Laws and Practice. (n.d.). Retrieved from http://gilc.org/privacy/survey/intro.htmlhttp://gilc.org/privacy/survey/intro.html retrieved 3.7.2018

Puttaswamy (Retired) \& Anor v Union of India \& Ors (Aadhaar case) WP (Civil) No 494/2012, 24 August 2017

Samuel D Warren, Louis D Brandeis (1890), The Right to Privacy, Harvard Law Review, Vol 4, No 5. (Dec 15, 1890)

Sivarasa Rasiah v Badan Peguam Malaysia [2010] 2 MLJ 333

Tan Tek Seng v Suruhanjaya Perkhidmatan Pendidikan \& Anor [1996] 2 AMR 1469, [1996] 1 MLJ 261

Toh See Wei v Teddric Jon Mohr \& Anor [2017] 1 LNS 1815 
Hashim, N., \& Mohd Yunus, A.S., CSSR2018, 5th International Conference on Science and Social Research, Le Meridien Kota Kinabalu Hotel, 5 - 6 Dec 2018, E-BPJ, 5(SI3), Dec 2020 (pp.289-295)

Ultra Dimension Sdn Bhd v Kook Wei Kuan [2004] 5 CLJ 285, [2001] MLJU 751

Yushri Zainudin v Silterra Malaysia Sdn Bhd (Wafer Technology (Malaysia) Sdn Bhd [2017] 1 LNS 2187 